\title{
Changes in Saponins Content of Some Selected Nigerian Vegetables during Blanching and Juicing
}

\author{
Odufuwa, Kuburat Temitope ${ }^{1}$, Atunnise, Adeleke ${ }^{1}$, Kinnah, Hudson joseph ${ }^{1}$, \\ Adeniji, P. $\mathrm{O}^{2}$ Salau, Bamidele Adewale ${ }^{3} *$ \\ ${ }^{1}$ Department of Biochemistry, faculty of Basic Medical Sciences Obafemi Awolowo College of health sciences \\ Olabisi Onabanjo University Ogun State Nigeria. \\ ${ }^{2}$ Department of Transport and Tourism Studies, Redeemer's University, Km 46 Lagos/Ibadan Expressway, \\ P.M.B. 3005, Redemption City, Mowe, Ogun state, Nigeria. \\ ${ }^{3}$ Department of chemical sciences, College of Natural Sciences, Redeemer's University, Km. 46 Lagos/Ibadan \\ Expressway, P.M.B. 3005, Redemption City, Mowe, Ogun state, Nigeria.
}

\begin{abstract}
Saponin, a secondary plant metabolite acts as both antinutrient and antioxidant in humans. It is usually affected by different processing methods, majorly heating. Though, vegetables are usually subjected to processing before consumption, however, recent interest in vegetable juice is gaining ground among the populace without consideration to the level of antinutrient and other toxic constituents that may be concentrated by juicing. Some selected vegetables, commonly consumed in south western Nigeria were evaluated for saponins content in the fresh, blanched and juiced forms using standard laboratory procedures. Variation exists in saponin content of vegetable and their products. Highest value of saponin was observed as follows; fresh Teliferia occidetalis 1332.70mg/100g; blanched Teliferia occidentalis $918.77 \mathrm{mg} / 100 \mathrm{~g}$ and juice Manihot esculenta $2286.82 \mathrm{mg} / 100 \mathrm{~g}$ dry weight. While lowest was observed in Talinum triangulare $123.82 \mathrm{mg} / 100 \mathrm{~g}$; launae taraxacifolia $141.75 \mathrm{mg} / 100$ and Basella rubra $132.03 \mathrm{mg} / 100 \mathrm{~g}$ dry weight respectively. Observations showed that blanching and juicing affected the saponin content of the vegetables differently, while the blanching reduced the content of saponin in most of the vegetables, juicing, however, concentrated some vegetables and reduced some. Also, saponin content of vegetables varies and affected by different processing methods. Thus, vegetable juice must be taken with caution by people vulnerable to saponin.
\end{abstract}

Keywords: Vegetable, saponin, blanched, fresh and antinutrients

\section{Introduction}

Saponins are a diverse group of low molecular-weight secondary plant metabolites that are widely distributed in the plant kingdom. They are glucosides with foaming characteristics. In addition to industrial applications as foaming and surface active agents, they have been used as detergents, piscicides and molluscicides [1]; antiviral [2]; antifungi [3].

Saponins exhibits wide range of pharmacological activities; they affect the immune system [4] help to protect the human body against cancers [5] and act as antioxidant [6] also possess hypolipidemic [7] and hypoglycemic properties [8]; and can be used in the inhibition of dental caries and platelet aggregation [9]. Saponin have been used the treatment of hypercalciuria and as an antidote against acute lead poisoning [9].

While saponins have been shown to have beneficial effect, studies have also shown the detrimental effects of saponins intake such as decreased degradability of feed protein [10], reduction in the total protozoa count in the rumen of sheep [11] and its contraceptive effect [12].

Vegetables contain various nutrients especially minerals, vitamins and phytochemicals which include glucosides, alkaloids, carotenoids, terpenoids and saponins. Phytochemicals are generally, non-nutritive plant chemicals that have potentials to affect diseases such as cancer, stroke or metabolic syndrome.

Majorly, these chemicals are produced by plants to protect themselves against diseases and pests but some have been shown to protect humans also. Green plants represent a reservoir of effective chemotherapeutants and provide valuable sources of natural pesticides $[13,14]$.

Saponin type depends on whether the plants is culivated or not the cultivated plants usually contain tripenoids saponin while the herbal plants contain steroidal saponin [12]. Vegetable which could be wild or cultivated are usually processed before consumption. Cooking, one of the processing methods of vegetables appeared to improve quality, such as taste, flavor, nutrient retention, bioavailability and the content of chemopreventive compounds in vegetables. Such processing methods have shown to affect the nature and level of saponins in plants [9].

In the past consumption of fresh (unprocessed) vegetable was uncommon, but of recent the use of vegetable juice such as Telferia occidentalis (probably for hemopoetic value) and Vernonia amygdalina 
(probably for antidiabetic and other therapeutic purpose) is on increase among Nigerian populace. While the juicing is believed to concentrate the nutrients, thus, the ant- nutrients which are ususally affected by heat may also be concentrated possibly to the level that might affect the consumer adversely.

In view of the above, we set to investigate the content of saponin, ant- nutrient in fresh vegetables and how its level is affected by blanching and juicing.

\subsection{Sample collection}

\section{Materials And Methods}

Vegetables used for the study were purchased from four major markets; Ago-iwoye, Ikenne and sagamu markets in Ogun state and Ketu market in Lagos state, Nigeria. The weight of the samples varied from $1-5 \mathrm{~kg}$. The samples were identified at the herbarium of the plant science and zoology department, Olabisi Onabanjo University.

\subsection{Sample preparation}

The vegetables purchased were destalked so as to get the edible part of the vegetables. Samples of each specimen (two from each market) were thoroughly mixed together and divided into four parts.

\subsubsection{Blanching}

The process of blanching of the vegetables was done by putting $200 \mathrm{~g}$ of vegetables in $500 \mathrm{ml}$ of boiled water and it was allowed to stay for five minutes. The vegetables were removed and then drained before analysis.

\subsubsection{Juicing}

This was carried out by using master chef juice extractor (model no: mc-J2101). The juice and pulp were collected separately.

\subsection{Sample analysis}

Moisture content

The moisture content of $10 \mathrm{~g}$ of each samples were determined. This was done by taking $10 \mathrm{~g}$ of each sample from each replicate (4 samples) into a $200 \mathrm{ml}$ crucible and then it was dried in oven at a temperature of $105^{\circ} \mathrm{c}$ for $24 \mathrm{Hr}$.

\subsection{Saponins content}

$0.5 \mathrm{~g}$ of the sample was added to $20 \mathrm{ml}$ of $1 \mathrm{NHCl}$ and was boiled for $4 \mathrm{~h}$. After cooling it was filtered and $50 \mathrm{ml}$ of petroleum ether was added to the filtrate for ether layer and evaporated to dryness. $5 \mathrm{ml}$ of acetone ethanol was added to the residue. $0.4 \mathrm{ml}$ of each was taken into 3 different test tubes. $6 \mathrm{ml}$ of ferrous sulphate reagent was added into them followed by $2 \mathrm{ml}$ of conc. $\mathrm{H}_{2} \mathrm{SO}_{4}$ It was thoroughly mixed after 10 minutes and the absorbance was taken at 490nm [13]

\subsection{Statistical analysis}

The experimental design was completely randomized. Data were analyzed using the Statistical Package for Social Sciences (SPSS) 16. Significant different between the data was determined at $\mathrm{p}<0.05$ using Duncan multiple range test.

\section{Result And Discussion}

Table 1: Saponins content of fresh leafy vegetables

\begin{tabular}{lllll}
\hline S/N & VEGETABLES & $\begin{array}{l}\text { ENGLISH/LOCAL } \\
\text { NAMES }\end{array}$ & $\begin{array}{l}\text { SAPONIN CONTENT } \\
(\mathrm{mg} / 100 \mathrm{~g} / \mathrm{dry} \text { weight })\end{array}$ & $\begin{array}{l}\text { MOISTURE CONTENT } \\
(\%)\end{array}$ \\
\hline 1 & Corchorus olitorius & Ewedu & $330.99 \pm 18.16^{\mathrm{d}}$ & $83.23 \pm 0.74^{\mathrm{b}, \mathrm{c}}$ \\
2 & Crassocephalum rubens & Ebolo & $281.61 \pm 10.68^{\mathrm{c}, \mathrm{d}}$ & $87.13 \pm 0.22^{\mathrm{f}, \mathrm{g}}$ \\
3 & Talinum triangulare & Water leaf & $123.82 \pm 6.13^{\mathrm{a}}$ & $84.58 \pm 0.03^{\mathrm{c}, \mathrm{d}, \mathrm{e}}$ \\
4 & Amaranthus viridis & Tete funfun & $467.56 \pm 28.95^{\mathrm{e}, \mathrm{f}}$ & $83.53 \pm 0.08^{\mathrm{b}, \mathrm{c}, \mathrm{d}}$ \\
5 & Ipomoea batatas & Sweet potato leaf & $222.50 \pm 23.36^{\mathrm{b}, \mathrm{c}}$ & $86.13 \pm 0.25^{\mathrm{e}, \mathrm{g},}$ \\
6 & Manihot esculenta & Cassava leaf & $434.26 \pm 75.21^{\mathrm{e}}$ & $85.08 \pm 1.33^{\mathrm{d}, \mathrm{e}}$ \\
7 & Telferia occidentalis & Pumpkin leaf & $1332.70 \pm 32.23^{\mathrm{g}}$ & $85.60 \pm 0.40^{\mathrm{e}, \mathrm{f}}$ \\
8 & Piper guineense & Uziza & $282.97 \pm 37.96^{\mathrm{c}, \mathrm{d}}$ & $85.33 \pm 0.69^{\mathrm{e}}$ \\
9 & Colocasia argentea & Ewe koko & $554.49 \pm 38.55^{\mathrm{f}}$ & $82.53 \pm 0.58^{\mathrm{a}, \mathrm{b}}$ \\
10 & Launaea taraxacifolia & Yanrin & $504.84 \pm 28.64^{\mathrm{e}, \mathrm{f}}$ & $87.55 \pm 0.67^{\mathrm{g}}$ \\
11 & Celosia argentea & Soko red & $274.27 \pm 2.42^{\mathrm{c,d}}$ & $82.50 \pm 0.00^{\mathrm{a}, \mathrm{b}}$ \\
12 & Basella alba & Amunututu white & $289.41 \pm 16.89^{\mathrm{c}, \mathrm{d}}$ & $91.50 \pm 0.00^{\mathrm{h}}$ \\
13 & Basella rubra & Amunututu red & $176.08 \pm 5.07^{\mathrm{a}, \mathrm{b}}$ & $81.40 \pm 0.00^{\mathrm{a}}$ \\
\hline
\end{tabular}


Results presented are mean \pm SEM $(n=4)$; values in the same column with the same superscript are not significantly different from each other $(\mathrm{P}>0.05)$.

Table 2: Saponins content of steamed leafy vegetables

\begin{tabular}{lllll}
\hline S/N & VEGETABLES & $\begin{array}{l}\text { ENGLISH/LOCAL } \\
\text { NAMES }\end{array}$ & $\begin{array}{l}\text { SAPONIN CONTENT } \\
(\mathrm{mg} / 100 \mathrm{~g} / \mathrm{dry} \text { weight })\end{array}$ & $\begin{array}{l}\text { MOISTURE } \\
\text { CONTENT }(\%)\end{array}$ \\
\hline 1 & Corchorus olitorius & Ewedu & $202.17 \pm 6.82^{\mathrm{a}, \mathrm{b}}$ & $87.03 \pm 0.41^{\mathrm{c}, \mathrm{d}}$ \\
2 & Crassocephalum rubens & Ebolo & $358.14 \pm 51.11^{\mathrm{b}}$ & $89.00 \pm 0.08^{\mathrm{d}, \mathrm{e}}$ \\
3 & Talinum triangulare & Water leaf & $328.49 \pm 19.78^{\mathrm{a}, \mathrm{b}}$ & $94.18 \pm 0.02^{\mathrm{f}}$ \\
4 & Amaranthus viridis & Tete funfun & $270.03 \pm 39.70^{\mathrm{a}, \mathrm{b}}$ & $87.65 \pm 1.76^{\mathrm{c}, \mathrm{d}, \mathrm{e}}$ \\
5 & Ipomoea batatas & Sweet potato leaf & $160.10 \pm 12.05^{\mathrm{a}, \mathrm{b}}$ & $85.93 \pm 0.43^{\mathrm{c}}$ \\
6 & Manihot esculenta & Cassava leaf & $218.54 \pm 17.94^{\mathrm{a}, \mathrm{b}}$ & $78.13 \pm 0.61^{\mathrm{a}}$ \\
7 & Telferia occidentalis & Pumpkin leaf & $918.77 \pm 213.61^{\mathrm{c}}$ & $87.28 \pm 0.60^{\mathrm{c}, \mathrm{d}, \mathrm{e}}$ \\
8 & Piper guineense & Uziza & $174.16 \pm 10.107^{\mathrm{a}, \mathrm{b}}$ & $87.78 \pm 0.35^{\mathrm{c}, \mathrm{d}, \mathrm{e}}$ \\
9 & Colocasia argentea & Ewe koko & $206.89 \pm 15.60^{\mathrm{a}, \mathrm{b}}$ & $85.88 \pm 0.70^{\mathrm{c}}$ \\
10 & Launaea taraxacifolia & Yanrin & $141.75 \pm 21.11^{\mathrm{a}}$ & $89.63 \pm 0.03^{\mathrm{e}}$ \\
11 & Celosia argentea & Soko red & $145.85 \pm 2.81^{\mathrm{a}, \mathrm{b}}$ & $81.83 \pm 0.12^{\mathrm{b}}$ \\
12 & Basella alba & Amunututu white & $147.83 \pm 25.11^{\mathrm{a}, \mathrm{b}}$ & $83.35 \pm 1.58^{\mathrm{b}}$ \\
13 & Basella rubra & Amunututu red & $212.34 \pm 26.71^{\mathrm{a}, \mathrm{b}}$ & $92.70 \pm 0.91^{\mathrm{f}}$ \\
\hline
\end{tabular}

Results presented are mean \pm SEM $(n=4)$; values in the same column with the same superscript are not significantly different from each other $(\mathrm{P}<0.05)$.

Table3: Saponins content of leafy vegetables juice

\begin{tabular}{lllll}
\hline S/N & VEGETABLES & $\begin{array}{l}\text { ENGLISH/LOCAL } \\
\text { NAMES }\end{array}$ & $\begin{array}{l}\text { SAPONIN CONTENT } \\
(\mathrm{mg} / 100 \mathrm{~g} / \mathrm{dry} \text { weight })\end{array}$ & $\begin{array}{l}\text { MOISTURE } \\
\text { CONTENT }(\%)\end{array}$ \\
\hline 1 & Corchorus olitorius & Ewedu & $589.41 \pm 96.73^{\mathrm{a}, \mathrm{b}}$ & $90.96 \pm 2.19^{\mathrm{b}, \mathrm{c}}$ \\
2 & Crassocephalum rubens & Ebolo & $1165.94 \pm 144.39^{\mathrm{b}}$ & $96.33 \pm 0.39^{\mathrm{e}, \mathrm{f}}$ \\
3 & Talinum triangulare & Water leaf & $339.84 \pm 21.52^{\mathrm{a}, \mathrm{b}}$ & $94.03 \pm 0.33^{\mathrm{d}, \mathrm{e}}$ \\
4 & Amaranthus viridis & Tete funfun & $895.95 \pm 75.41^{\mathrm{a}, \mathrm{b}}$ & $93.35 \pm 0.09^{\mathrm{c}, \mathrm{d}}$ \\
5 & Ipomoea batatas & Sweet potato leaf & $339.93 \pm 70.39^{\mathrm{a}, \mathrm{b}}$ & $95.70 \pm 1.02^{\mathrm{d}, \mathrm{e}, \mathrm{f}}$ \\
6 & Manihot esculenta & Cassava leaf & $2286.82 \pm 581.90^{\mathrm{c}}$ & $95.20 \pm 1.34^{\mathrm{d}, \mathrm{e}, \mathrm{f}}$ \\
7 & Telferia occidentalis & Pumpkin leaf & $375.84 \pm 93.53^{\mathrm{a}, \mathrm{b}}$ & $95.55 \pm 0.45^{\mathrm{de}, \mathrm{f}}$ \\
8 & Piper guineense & Uziza & $476.51 \pm 56.31^{\mathrm{a}, \mathrm{b}}$ & $95.08 \pm 0.52^{\mathrm{d}, \mathrm{e}, \mathrm{f}}$ \\
9 & Colocasia argentea & Ewe koko & $160.68 \pm 15.10^{\mathrm{a}}$ & $87.92 \pm 0.72^{\mathrm{a}}$ \\
10 & Launaea taraxacifolia & Yanrin & $1197.42 \pm 718.34^{\mathrm{b}}$ & $97.73 \pm 0.63^{\mathrm{f}}$ \\
11 & Celosia argentea & Soko red & $618.94 \pm 8.44^{\mathrm{a}, \mathrm{b}}$ & $88.15 \pm 0.06^{\mathrm{a}}$ \\
12 & Basella alba & Amunututu white & $486.41 \pm 38.42^{\mathrm{a}, \mathrm{b}}$ & $97.35 \pm 0.19^{\mathrm{f}}$ \\
13 & Basella rubra & Amunututu red & $132.03 \pm 4.65^{\mathrm{a}}$ & $89.03 \pm 0.75^{\mathrm{a}, \mathrm{b}}$ \\
\hline
\end{tabular}

Results presented are mean $\pm \operatorname{SEM}(n=4)$; values in the same column with the same superscript are not significantly different from each other $(\mathrm{P}<0.05)$.

Shown in Table 1 is the saponin content in fresh vegetable, lowest value was observed in Talinum triangulare $123.83 \pm 6.13 \mathrm{mg} / 100 \mathrm{~g}$ dry weight; followed by Basella ruba. Though, no significant difference ( $>$ >0.05) was observed in saponin content of Ipomoea batatas 222.50 \pm 23.36 , Celosia argentea 274.29 \pm 2.42 , Crassocephalum rubens 281.61 \pm 10.68 , Piper guineense 282.96 \pm 37.96 and Basella alba 289.41 \pm 16.89 which ranges from 175 to $300 \mathrm{mg} / 100 \mathrm{~g}$ dry weight. However, they are significantly lower than Manihot esculenta 434.26 \pm 75.21 , Amaranthus viridis 467.56 \pm 28.95 , Launaea taraxacifolia 504.84 \pm 28.64 , Colocasia argentea $554.49 \pm 38.55$ and Telferia occidentalis with the highest value observed in Telferia occidentalis.

Table 2 showed the effect of blanching on saponin content of green leafy vegetable, no significant difference $(p<0.05)$ was observed in virtually all the vegetable except in Launaea taraxacifolia 141.75 \pm 21.11 and Crassocephalum rubens 358.14 \pm 51.11 , however, highest value $(\mathrm{p}<0.05)$ was still observed in Telferia occidentalis $918.77 \pm 213.61$ when compared with other vegetables.

Significant difference $(\mathrm{p}<0.05)$ was observed between Crassocephalum rubens 358.14 \pm 51.11 and Launaea taraxacifolia 141.75 \pm 21.11 , Crassocephalum rubens $358.14 \pm 51.11$ and Telferia occidentalis 918.77 \pm 213.61 . No significant difference $(\mathrm{p}>0.05)$ was observed between Celosia argentea 145.85 \pm 2.81 , Basella alba 147.83 \pm 25.11 , Ipomoea batatas $160.10 \pm 12.05$, Piper guineense $174.16 \pm 10.11$, Corchorus olitorius 202.18 \pm 6.82 , Colocasia argentea 206.87 \pm 15.60 , Basella rubra 212.34 \pm 26.71 , Manihot esculenta 218.54 \pm 17.94 , Amaranthus viridis $270.03 \pm 39.70$ and Talinum triangulare $328.49 \pm 19.78$. 
Table 3 reflected the saponin content in vegetable juice, no significant difference $(\mathrm{p}>0.05)$ was observed in most of the vegetables. However, a clear cut difference $(\mathrm{p}<0.05)$ only exists when Manihot esculental 2286.82 \pm 581.90 was compared with Lunea taraxacifolia 1197.42 \pm 718.34 and Ammarantus viridus $895.95 \pm 75.41$ which were significantly $(\mathrm{p}<0.05)$ different from Colocacia argentea $160.675 \pm 15.10$ and Basella rubra $132.03 \pm 4.65$.

\section{Discussion}

Studies have shown that majority of plants contain saponins, the cultivated crops usually contain triterpenoids saponin while the herbal plants contain steroids saponin [12]. Also, variation exist in saponin content of different vegetables and are affected by processing methods. [16].

This study revealed variation in saponin content of different vegetables and effect of blanching which reduced saponin content virtually in all the vegetables. Variation in saponin content of vegetable juice was not as pronounced as observed in fresh vegetables except in Crassophalium ruben, Launaea taraxacifolia and Manihot esculenta which exhibit high value in order of thousands (1000)mg saponin /100g dry vegetable juice extracts. However, blanching tends to reduce the saponin in most vegetables examined.

Observed variation in saponin content of various green leafy vegetables studied, showed that different vegetables have ability to produce these secondary metabolites as a result of genetic constitution of the plants and or other environmental factors [17, 18]. High saponin levels were observed in Telferia ocidentalis, Colocacia argente, Lunea taraxacifolia and Ammmarantus viridis, having saponin in $\mathrm{mg} / 100 \mathrm{~g}$ dry weight, well above 400. Such high level concentration of saponin may necessitate processing that might reduce level of saponin because of its ant- nutrients and other undesirous features such as increasing the permeability of the small intestine, growth impairment and decreased food conversion [19, 20] and effect on fertility [21, 22]. Thus, intake of these vegetables without proper processing may lead to saponin toxicity, for instance consumption of $100 \mathrm{~g}$ of fresh Telferia occidentalis would expose the consumer to about $186 \mathrm{mg}$ of saponin. The high level of saponin observed in Teleferia occidentalis, this was consistent with Ukpabi and Akubugwo, 2011 [23] findings, though this is contrary to the findings of Mensah and others [23].

Heating (blanching) appear to effect drastic reduction on the saponin content of the vegetables except Telferia occidentalis which appeared relatively higher when compared with other vegetables. This is consistent with findings of Adeboye and Babajide, 2007 which revealed lowering effect of heat on saponin content [16]. Juicing, concentrated saponin content of most vegetables observed, though beneficial effect of saponin cannot be over emphasized, however, the intake above recommended dosage might cause deleterious effects such as ferrous complexation and excretion [25] which may affect red blood status, complextion of proteins [26] that may lead to growth depression and also its negative effect on fertility. It may also reduce antioxidant activities by complexing zinc, managamesse $[25,18]$ which are necessary for cytosolic and mitochrondria superoxide dismutase, thus it is advisable to exercise care when taking the juice of high saponin containing vegetables such as Crassophalium ruben, Launaea taraxacifolia and Manihot esculenta. However, the high level of saponin observed in C. ruben might give it a strong inhibitory activities against bacterial by inhibiting protein synthesis and increasing oxidative stress in the cytoplasm of the bacterial as reported by Gbadamosi and others [27].

\section{Conclusion}

This study revealed variation in saponin concentration of various vegetables commonly consumed in South-western Nigeria and effect of processing on its level, thus it suggests vegetables with saponin level should be taken with caution because of the undesirous effect of saponin if consumed in large doses. The results also showed that heat treatment reduces saponin to minimal level, which suggests blanching of vegetable should be encouraged. Juicing of certain vegetables may concentrate saponin to a considerable level that may affect the consumer adversely, hence such vegetable juice must be taken with precaution especially in vulnerable group (children and pregnant women, old age and aneamic subjects) where high level of saponin may be deleterious to health.

We opined that these results would be useful to nutritionist, toxicologist and food scientist and various researchers in biomedical fields.

\section{Acknowledgement}

We acknowledge college of Natural sciences, Redeemers University for granting the laboratory space for this work, also special thanks to Professor G. A. Kolawole the Head of Department of chemical sciences for his moral support.

\section{Refrences}

[1] Jan Alexander, Guðjón Atli Auðunsson, Diana Benford, Andrew Cockburn, Jean-Pierre Cravedi, Eugenia Dogliotti, Alessandro Di Domenico, María Luisa Férnandez-Cruz, Johanna Fink-Gremmels, Peter Fürst, Corrado Galli, Philippe Grandjean, Jadwiga Gzyl, Gerhard Heinemeyer, Niklas Johansson, Antonio Mutti, Josef Schlatter, Rolaf van Leeuwen, Carlos Van Peteghem, Philippe 
Verger. Scientific Opinion of the Panel on Contaminants in the Food Chain on a request from the European Commission on Saponins in Madhuca Longifolia L. as undesirable substances in animal feed. The EFSA Journal (2009) 979, 1-36.

[2] Apers S, Baronikova S, Sindambiwe JB, Witvrouw M, De Clercq E, Vanden Berghe D, Van Marck E, Vlietinck A \& Pieters L (2000) Antiviral, haemolytic and molluscicidal activities of triterpenoid saponins from Maesa lanceolata: establishment of structureactivity relationships. Planta Medica 67, 528-532.

[3] Delmas F, Di Giorgio C, Elias R, Gasquet M, Azas N, Mshvildadze V, Dekanosidze G, Kemertelidze E \& Timon-David P (2000) Antileishmanial activity of three saponins isolated from ivy, alpha-hederin, beta-hederin and hederacolchiside A(1), as compared with their action on mammalian cells cultured in vitro. Planta Medica 66, 343-347.

[4] Oda K, Matsuda H, Murakami T, Katayama S, Ohgitani T \& Yoshikawa M (2000) Adjuvant and haemolytic activities of 47 saponins derived from medicinal and food plants. Biological Chemistry 381, 67-74.

[5] Park HJ, Kwon SH, Lee JH, Lee KH, Miyamoto K \& Lee KT (2001) Kalopanaxsaponin A is a basic saponin structure for the antitumor activity of hederagenin monodesmosides. Planta Medica 67, 118-121.

[6] Hu J, Lee SO, Hendrich S \& Murphy PA (2002) Quantification of the group B soyasaponins by high-performance liquid chromatography. Journal of Agricultural and Food Chemistry 50, 2587-2594.

[7] Matsuura M (2001) Saponins in garlic as modifiers of the riskof cardiovascular disease. Journal of Nutrition 131, 1000S-1005S.

[8] Yoshiki Y, Kudou S \& Okubo K (1998) Relationship between chemical structures and biological activities of triterpenoid saponins from soybean (Review). Bioscience Biotechnology and Biochemistry 62, 2291-2299.

[9] Yeung, N., Botvinick, M. M, Cohen, J. D., The neural bais of error detection: conflict monitoring and the error related negativity. Psychol. Rev. 111, $931-959$.

[10] Makkar HPS \& Becker K (1996) Effect of Quillaja saponins on in vitro rumen fermentation. In Saponins Used in Food and Agriculture, pp. 377-386 [GR Waller and Y Yamasaki, editors]. New York: Plenum Press.

[11] Lu CD \& Jorgensen NA (1987) Alfalfa saponins affect site and extent of nutrient digestion in ruminants. Journal of Nutrition 117, 919-927.

[12] Francis G, Makkar HPS \& Becker K (2002) Effects of cyclic and regular feeding of Quillaja saponin supplemented diet on growth and metabolism of common carp (Cyprinus carpio L). Fish Physiology and Biochemistry 24, 343-350.

[13] Cowan, M.M (1999). "Plant products as antimicrobial agents." Clinical Microbiolgy

[14] Verma, R.K. and Verma, S.K. (2006). "Phytochemical and termiticidal study of lantana camara var. arculeate leaves." Fitoterapia 77 (6): 466-468.

[15] Oyedele DJ, Asunogho C, Awotoye OO (2006). Heavy metals in soil and accumulated by Edible vegetables after phosphate fertilizer application, Electron J. Environ. Agric. Food Chem., 5(4): 1446-1456. Pearson D (1976). Chemical Analysis of foods (7th Ed) churchill, Livingstone, London, pp. 218-336.

[16] Adeboye, A.S and Babajide, J.M. (2007). "Effect of processing Methods on anti-nutrients in selected Leafy Vegetables". Nigerian Food Journal. 25(2):77-87.

[17] Szakiel A, Packowski C, Henry M. (2011) influence of environmental biotic factor on content of saponin in plants phytochemistry Review vol. $10(493-502)$

[18] Hong K. J., S. Tokunga, Y. Ishigami, T Kajichi (2000). Extraction of heavy metal from MSW incinerator fly ash using saponin: Chemosphere $41 ; 345-352$.

[19] Gee JM \& Johnson IT (1988) Interactions between haemolytic saponins, bile salts and small intestinal mucosa in the rat. Journal of Nutrition 118, 1391-1397.

[20] Gee JM, Price KR, Ridout CL, Wortley GM, Hurrell RF \& Johnson IT (1993) Saponins of quinoa (Chenopodium quinoa): Effects of processing on their abundance in quinoa products and their biological effects on intestinal mucosal tissue. Journal of the Science of Food and Agriculture 63, 201-209.

[21] Quin G-W \& Xu R-S (1998) Recent advances in bioactive natural products from Chinese medicinal plants. Medical Research Reviews 18, 375-382.

[22] Dorsaz A-C, Hostettmann M \& Hostettmann K (1988) Molluscicidal saponins from Sesbania sesban. Planta Medica 54, 225-227.

[23] Ukpabi chibueze and Akubugwo E. I. (2011). Nutritive values and phytochemical contents of some leafy vegetables grown with different fertilizers; Agriculture and Biology journal of North America 2 (12)

[24] Mensah. J.K., Okoli R.I., Ohaju-Obodo .J.O. and Eifediyi K. (2008), Phytochemical, nutritional and medical properties of some leafy vegetables consumed by Edo people of Nigeria. African Journal of Biotechnology Vol. 7 (14), pp. 2304 - 2309.

[25] Southon S, Johnson IT, Gee JM \& Price KR (1988) The effect of Gypsophylla saponins in the diet on mineral status and plasma cholesterol concentration in the rat. British Journal of Nutrition 59, 49-55.

[26] Potter SM, Jimenez-Flores R, Pollack J, LoneTA\&Berber-Jimenez MD (1993) Protein saponin interaction and its influence on blood lipids. Journal of Agricultural and Food Chemistry 41, 1287-1291.

[27] Gbadamosi I. T. Alia A. E. and Okolosi O. (2012) In-vitro Antimicrobial Activities and Nutritional Assessment of Roots of Ten Nigerian Vegetables; New York Science Journal 5(12). 